This is an Accepted Manuscript of an article published by Taylor \& Francis in Sport in Society on 8/6/2020, available online:

https://doi.org/10.1080/17430437.2020.1772235

\title{
Shifting dominant logics? The organisational field of Finnish sport clubs in the 2010s
}

This research, which draws upon the new institutionalist approach, investigates the changing dominant logics of voluntary sport clubs in Finland. Data were collected by conducting 41 semi-structured expert interviews with sport clubs and obtaining club documents. Results reveal a widening range of roles, networks, and participant pathways, as well as an increasingly formalised operation and diversified language-use. As a result, many clubs have experienced challenges in maintaining their legitimacy when operating in new domains that diverge from their traditional operations. The findings reflect growing expectations placed upon sport clubs and their shifting roles across the public, private and third sectors. Further, it is argued that understanding the logics of all three sectors have become necessary in order for sport clubs to run successfully. The findings will be of interest to federations, institutes providing tertiary education, as well as to clubs that are in the process of refining their profile.

Keywords: sport club, new institutionalism, organisational field, dominant logics, Finland

\section{Introduction}

To meet growing expectations that they might provide solutions to a range of societal problems, European sport clubs have been driven to move beyond their traditional, more straightforward roles as volunteer organisations (Nagel et al. 2015). As a result, these clubs now differentiate their activities and cooperate with a growing variety of stakeholders including schools as well as sport providers in the private sector (Nagel et al. 2015; Szerovay, Perényi, and Itkonen 2016). The coexistence of traditional amateur 
ideals and emerging commercial interests has created tensions (Stenling and Fahlén 2009), helping to shape relationships within sport clubs (Van der Roest 2016).

Simultaneously, the appearance of other sport providers in the field has challenged their monopoly over sport-related services (Schlesinger and Nagel 2015). In addition, municipality policies - those emphasising the desired social roles of voluntary sport clubs, which may not correspond to the self-perception of the clubs themselves-have put them under increasing pressure (Waardenburg 2016).

These conditions suggest a shift in shared values and common practices as well as the appearance of conflictual interests. Scott (2014) points out that for organisations in a conflicting environment, maintaining legitimacy may be a challenge. As a result, sport clubs may be driven to adjust their profile or even reposition themselves. We need more understanding about these shifts affecting sport clubs. We should also explore how sport clubs have adapted to the aforementioned demands (Vos et al. 2011). To address these needs, studies should include qualitative designs that give clubs voice and provide insights into their experience. Although sport clubs share common features across countries, examining different contexts can reveal differences in their positioning and functioning (Nagel et al. 2015). Concerning the Finnish context, there has been little qualitative research about developments over the past decade. Existing studies highlight the pressure to professionalise various aspects of sport clubs. This, in part, stems from the disparity between the changing environment and the limited capacity of volunteer activities (Koski and Mäenpää 2018).

In this paper, using a new institutionalist approach and employing a qualitative inquiry, I focus on Finnish voluntary sport clubs and their environment. The new institutionalist approach looks at the making of social and cultural values, rules, symbols and procedures that shape interactions in an organisational field (DiMaggio 
and Powell 1983; Scott 2014). This perspective — with its focus on processes that take place in the environment of organisations - allows me to explore changes that result from formal and informal expectations (Augestad, Bergsgard, and Hansen 2006). The organisational field refers to 'those organizations that, in aggregate, constitute a recognised area of institutional life' (DiMaggio and Powell 1983, 148). This is a broad definition including all the relevant interconnected actors in a field. In the context of this article it denotes sport clubs, participants, umbrella organisations, municipalities and service providers such as self-employed professional coaches.

Key components of the field are the institutional or dominant logics.

Institutional logics imply shared understandings that encourage participants to behave in a certain way in the organisational field (Scott 2014). For instance, Skirstad and Chelladurai (2011) identified amateur, professional and commercial logics at work when analysing a Norwegian football club. Other scholars conceptualised the shared ideas and beliefs held by participants as the dominant logics (Bettis and Prahalad 1995; Stenling and Fahlén 2009). Dominant logics give directions regarding the legitimate ways in which activities can be undertaken (Bettis and Pralahad 1995). By striving for legitimacy, organisations attempt to align their activities to the environment (DiMaggio and Powel 1983). That is, pressures in the field often drive organisations towards similarity. Nevertheless, institutional mechanisms may also result in variations in the field (Skille 2008). For example, the coaching principles proposed by a national football federation might be implemented by clubs in different ways depending on their local philosophy and understanding of those principles.

As mentioned above, the main concepts of new institutional theory informing this paper are the organisational field and the dominant logics. Employing the dominant logics allows me to discuss signposts that 'indicate shifting logics and change in an 
organisational field' (O'Brien and Slack 2003, 422). In the process, I explore how sport clubs have adjusted to as well as shaped the organisational field in order to maintain legitimacy. Indeed, sport clubs can be seen as both the products and the producers of the institutional environment. Accordingly, the following research questions guide the study: How have the dominant logics shifted in the organisational field of Finnish sport clubs in the 2010s? How have sport clubs adjusted to this shift?

The remainder of this article is organised as follows. I start by outlining the voluntary sport club context in Finland. Second, I review the related literature about new institutionalism and sport, and introduce the conceptual framework employed in this study. Third, the research process is described, followed by the results and discussion section where I explore key findings identified in the research data and display them in tabulated form. Finally, I advance concluding thoughts.

\section{Voluntary sport clubs in Finland: The context}

Civic society in Finland emerged in the second half of the $19^{\text {th }}$ century (Alapuro 2010). As part of civic society, sport and physical activities have traditionally formed an organic part of people's lives. Sport clubs in European countries, characterised by the interests of members, democratic decision-making, autonomy, not-for-profit operation and solidarity (Heinemann 2004), have played significant roles in civic society; they have fulfilled a crucial function of sport provision and in carrying out sport policy, particularly at the grassroots level (Vos et al. 2011; Skille 2009).

In Finland, sport provision promotes good health, contributes to a process of socialisation, strengthens social identity and, more recently, creates employment (Vehmas and Ilmanen 2013). Since the 1980s - the period named the age of divergent activity in sport culture by Itkonen (2002) — sport clubs have become increasingly differentiated, exhibiting this diversity in, for example, their size, the focus of activities 
and the extent to which people are employed. Team sports have become more popular, while associations that do not belong to central federations have been founded. New types of activities, such as e-sports and fan organisations, have also emerged (Koski and Mäenpää 2018). The number of sport clubs currently in operation is approximately 10,000 (Koski and Mäenpää 2018).

Volunteer work has played a key role in maintaining this system (Koski et al. 2015). Although there is evidence of a downward trend over the past decade, Finnish citizens' engagement in sport-related voluntary activities remains well above the European average (Eurobarometer 2017). Most Finnish sport clubs continue to be based on voluntary activities; however, between 1986-2016 the share of clubs with paid staff has grown from $7 \%$ to $21 \%$ (Koski and Mäenpää 2018). Public subsidy schemes put in place since the 2000s, focusing primarily on enhancing employability in sport clubs and providing a broader range of services to non-members, have also appeared (Koski and Mäenpää 2018). The growing cost of participation in physical activities-contributing to social inequality by limiting access to certain social groups-has also been observed in past decades (Puronaho 2014).

The public sector, specifically the state and municipalities, has traditionally provided and maintained sports facilities, while sport clubs, which belong to the third or voluntary sector, have organised activities that would take place on these sites (Koski et al. 2015). Simultaneously, the significance of the private sport sector, which creates sport-related business opportunities, has increased (Laine and Vehmas 2017).

Studies on Finnish sport clubs carried out to date have relied on two main perspectives: First, research conducted with a primarily quantitative focus, emphasising the organisational effectiveness of clubs (e.g., Heinilä 1989; Koski 2000; 2009; 2012; Koski and Mäenpää 2018); second, research that employs qualitative, historical- 
sociological approaches, with case studies of a small number of clubs (e.g., Itkonen 1991; 1996; Itkonen and Nevala 2012; Szerovay, Perényi, and Itkonen 2016). In addition, there are descriptive research reports (e,g., Mäenpää and Korkatti 2012). The following study — using interview data and documents from a wide range of clubsoffers a qualitative approach centring its attention on institutional processes in the organisational field level in the 2010s.

\section{New institutionalism, organisational fields and dominant logics}

The theoretical background of this article is formulated around the new institutionalist approach. Emerging in the 1970s, it initially addressed how organisations in a field appear to be increasingly alike in their behaviours and structures due to external pressures (DiMaggio and Powell 1983). Over more recent decades, it has seen a shift in focus from individual organisations to field-level approaches and from institutional stability to institutional change, while it has also become more evidence-based (Scott 2008). Sport clubs in Europe have been looked at through the lens of new institutionalism (Vos et al. 2011; Nagel et al. 2015).

The concept of a field enables an additional level of analysis above an organisation (Skille 2011), broadening our focus to incorporate 'relevant actors, institutional logics, and governance structures that empower and constrain the actions of participants' (Scott 2014, 258). A field typically follows dominant logics (Bettis and Prahalad 1995; Stenling and Fahlén 2009), which encompass 'important criteria for legitimate organisational activities' (O'Brien and Slack 2003, 422). Dominant logics can be understood as a knowledge structure as well as management processes that facilitates decision making (Pralahad and Bettis 1986). Crucially, dominant logics act as a filter, guiding the attention of the actors and the organisation towards information that is seen as relevant and legitimate (Bettis and Pralahad 1995). 
As demonstrated in the analysis of the Swedish sport movement by Stenling and Fahlén (2009), more than one dominant logic may appear in a field. These logics—such as sport-for-all, a results-oriented approach or commercialization-may compete or collaborate with one another (Stenling and Fahlén 2009). Multiple logics experienced by a sport organisation may also be conceptualised from different angles; Skirstad and Chelladurai (2011) argue that a sport organisation may be present in different organisational fields and, therefore, needs to be aligned with each of them. Pluralistic environments in which sport clubs are embedded might present challenges for organisations to maintain their legitimacy (Scott 2014).

\section{Theoretical framework}

Following the theoretical leads of DiMaggio and Powell (1983), Pralahad and Bettis (1986), Bettis and Prahalad (1995) and O'Brien and Slack (2003; 2004), indicators of change in an organisational field's dominant logics can be identified. More specifically, I draw on a coding scheme consisting of four indicators, applied by O'Brien and Slack (2003), which they used to analyse the field-level changes of English Rugby Union since the mid-nineties. Although the authors focussed on senior clubs employing professional athletes, their paper carries useful implications for this article, as similar issues were identified in my interview data with Finnish voluntary sport clubs.

The first indicator of an organisational field's dominant logics covers the changes in the number and the nature of actors. Bettis and Pralahad (1995) suggest that the dominant logics are collected and stored in so called cognitive maps by the actors. These cognitive maps develop through actors' earlier experiences. When new actors such as specialists from the private sector enter the organisational field with different values and goals as compared with existing actors, the dominant logics might shift (Greenwood and Hinings 1996). This shift in turn shapes power balances in the field 
which then may affect the second indicator, namely exchange processes and interorganisational linkages. This indicator, first, facilitates the diffusion of information and innovative practices, and second, highlights the interdependence and connectedness of actors in the field (O'Brien and Slack 2004). Changing exchange processes can be exemplified by emerging tensions between professionals and volunteers; further, professionals may have to compromise with nonprofessional actors such as clients, bosses and regulators (DiMaggio and Powell 1983). Interorganisational linkages can be illustrated by new types of political coalition such as cooperation between governing bodies (O'Brien and Slack 2003).

The third indicator encompasses shifts in the legitimate forms of capital. According to Bourdieu and Wacquant (1992), actors in a field attempt to gain access to, or control over, forms of capital. Access to the right combination of capital can secure resources, power and legitimacy for organisations. Further, capital is field-specific. That is, depending on the field, cultural, social or economic capital may be emphasised. These differences were exemplified by the increased use of business vocabulary and the decreased legitimacy of perceived intrinsic rewards of volunteering (O'Brien and Slack 2003). Recognising the interdependence among dominant capital, interest of actors and political activity may be helpful in understanding the fourth indicator.

The final indicator is changes in regulatory structures. These changes are evident in the structuring of membership-based clubs and in the ways governing bodies exercise power (O'Brien and Slack 2003). The coding scheme presented above resonates with my results. Therefore, drawing on these leads allowed me to explore and discuss the shifting dominant logics in the organisational field of Finnish sport clubs by analysing changes in these indicators. 


\section{Research data and methodology}

The research data comprise 41 semi-structured expert interviews conducted with Finnish voluntary sport clubs between 2014 and 2017. Expert interviews attempt to bring facts to light through the interaction between the interviewer and the interviewee (Alastalo and Åkerman 2010). In this case, the specific expert knowledge involves the sport clubs. Accordingly, one representative from each club, such as the chairman, the general manager or another official, was interviewed.

Finnish undergraduate students in the Research Methods in Social Sciences of Sport module carried out the interview sessions. Classes took place at the Faculty of Sport and Health Sciences at the University of Jyväskylä, Finland. The students gathered the data as part of this module and were tutored by the author. The sessions included a three-hour seminar to train the students before the data collection. In this seminar we covered the theory and practice of interviewing and familiarised ourselves with the interview guide used in this study. Convenience sampling was employed in order to select clubs that were accessible given the available resources (Sparkes and Smith 2014). Students selected a club and contacted it using a covering letter I provided. Students subsequently called the club and scheduled a face-to-face interview. 26 of the 41 clubs came from the Central Finland region. Although the sample was, therefore, not representative geographically of the entire country, twenty sports disciplines and, in addition, six multi-sport clubs were included. The variety of clubs is also reflected in the number of registered participants, ranging from 50 to 1600 , and revenues, stretching from $€ 4500$ to $€ 1$ million. The oldest club in the data set was founded in 1896 and the newest has operated since 2008.

The interview guide covered the following: the role of the interviewee; the range of roles in the club; embeddedness in the local environment; publicity; resources; the 
goals of the club; sporting activities; competitiveness and coaching. These areas are based on Itkonen's (1991) and Szerovay, Perényi, and Itkonen's (2016) framework, in which the main aspects of the changing operations of sport clubs were explored. The interview guide was moderately structured (Wengraf 2001), which enabled the comparison of data across different clubs. The questions were in some cases adapted to the specificities of respective clubs. Emphasis was placed on youth activities, and on the timeframe of the 2010s. Interviews lasted c.60 minutes, and all sessions were recorded. After the interview sessions, a two-hour seminar took place in order to discuss the results and students' experiences of the data-collection process.

In addition to data acquired from these sessions, I used club documents such as annual plans, manuals and coaching guidelines to gain additional information and to ensure data reliability. A section of the interview guide consisted of questions related to these documents. When interviewees pointed out that these documents existed, I accessed those documents on the clubs' websites. For the most part, these documents are publicly available in Finland.

Key points of the interviews were summarised by the students, which facilitated the subsequent processes of data analysis. I produced a thematic analysis of the interview data and club documents, during the process of which I applied what Saunders, Lewis, and Thornhill (2016) call 'data sampling', transcribing the most relevant parts of the recordings. I applied a combination of theory- and data-driven coding (Braun and Clarke 2006) drawing on O'Brien and Slack's (2003) analytical framework presented in the theoretical framework. This enabled continuous two-way traffic between the theory and emerging data. I followed the six phases of analysis that Braun and Clarke (2006) suggest, comprising the following steps: becoming familiar 
with and transcribing the data; generating initial codes; searching for themes; reviewing themes; defining and naming the themes; producing the report.

The results of the analysis are presented in a table in the results and discussion session. The interviews took place in Finnish, while similarly the documents were in Finnish, but the coding frame was constructed in English. The quotations presented in the results and discussion section are translations undertaken by me.

\section{The changing field of Finnish sport clubs}

In line with the research questions and the theoretical framework presented, in this section I focus on changes in the indicators of dominant logics. In the process, I explore sport clubs' adaptation to these changes. My findings are shown in Table 1. The indicators in the left-hand column, as well as the sections of the discussion, follow O'Brien and Slack's (2003) coding scheme, except for the first two areas, which I merged. The right-hand column displays the themes I identified.

Table 1 Shifting logics in the organisational field of sport clubs

\begin{tabular}{ll}
\hline \multicolumn{1}{c}{ Indicators } & \multicolumn{1}{c}{ Themes } \\
\hline $\begin{array}{l}\text { Number and nature of actors, and } \\
\text { exchange processes }\end{array}$ & a) Stakeholders from all three sectors \\
& b) Increasingly complex division of labour \\
\hline cegitimate forms of capital & $\begin{array}{l}\text { d) Intensifying exchange of resources among } \\
\text { stakeholders }\end{array}$ \\
\hline a) Clubs becoming employers \\
\hline b) Increasing expectations of facilities \\
c) Changing language on a diversified field
\end{tabular}




\section{Number and nature of actors, and exchange processes}

My data reflects that the distribution of labour in Finland across the three sectors has shifted. Accordingly, stakeholders from the private and public sectors have increasingly been involved in the sport club field; these stakeholders have brought in experiences and practices from other fields. Professionals have appeared and replaced volunteers in several management and coaching roles. Outsourcing certain aspects of coaching — such as strength and conditioning as well as goalkeeper coaching - to specialists, is a case in point. Such services are often provided by companies or self-employed professionals.

Regarding the role of the public sector in sport club activities, cooperation with schools and day-cares has become common in the form of afternoon clubs for pupils organised by clubs, implying the expansion of the organisational field. The general manager of an ice hockey club commented: 'Recently, we have started to teach basic skating skills and games that can be played on ice to children in day-cares'. This link between schools and clubs has become more apparent as people have been employed in sport clubs, many of them with a background in pedagogical studies. Organising these activities have provided additional income for sport clubs; however, those in charge of physical activities in schools and day-cares might be of the opinion that sport clubs have encroached on their territory.

With their widening scope of operation, the variety of roles and the division of labour have also become more complex within clubs. Interviews and club websites have revealed that the roles of general manager, head of youth, head of coaching and club coordinator are just some of the titles that have appeared in recent years. The status of these actors ranges from volunteers to full-time employees. For example, the chairman of a basketball club pointed out that 'a part-time strength and conditioning coach is 
about to start that will be available to all of our teams'. Sport clubs often adapt these titles to their local context, goals, and financial capacities. Employing people has also impacted on their boards as clubs have begun to allocate specific roles to board members. For instance, officials appointed might oversee personnel, events, finances, coaching, or communication. By occupying these roles, board members-who oversee the strategic directions of clubs_-bring in specific knowledge and potentially different values onto the field that can conflict with clubs' traditional association logic.

In line with the changes above, clubs have been able to provide more diverse pathways to participants, and even enabling them to shift into coaching or administrative roles. As the chairperson of a gymnastics club put it: 'On the competitive section of our club, we have a pathway for coaches where we defined what level of license they need for coaching specific teams'. That is, clubs have attempted to sharpen their profile as a competitive or recreational club. This implies that multiple, at times conflicting, institutional processes — often resulting in standardised coaching practices and pressures to differentiate a club's profile — may lead to heterogeneity in the field (See Boxenbaum and Jonsson 2008). However, even though a club has branded itself as competitive, typically it offers activities for a diverse group of participants. An example is the development of commercial ancillary activities such as staging summer camps and tournaments that can cross-subsidise a club's core activities. Further, these activities often provide job opportunities to youth who would otherwise stop being involved in the club after dropping out as a participant. An additional aspect of participant pathways is that they may stretch across clubs; a talented player aged fourteen might move to another club with which her previous club has a formal agreement. Indeed, potential pathways have become more systemic and flexible at the same time. 
In part, the aforementioned changes have been driven by the intensifying exchange of economic and intangible resources between stakeholders. An example is the regular meetings for general managers and head of coaches organised by regional sport federations. Participation by club representatives in these events provide 'professional networks that connect organisations and facilitate the diffusion of normative rules about legitimate organisational and professional behavior' (O'Brien and Slack 2004). In addition, the geographical scope of operation has expanded in many cases as competitions over regional boundaries and participation in international youth tournaments, especially in ball games, has become more widespread. As the head of youth of a grassroots football club commented: 'Competitions stretching over district boundaries appeared and we now travel a bit more, which has an impact on the travelling expenses'.

\section{Legitimate forms of capital}

The shift in the nature of actors and exchange processes, discussed above, carries implications for the various forms of capital present in the organisational field of sport clubs. Three types of field-specific capital stood out that suggest a shift in the dominant values and logics. In accordance with the emergence of new positions presented in the previous section, the first encompasses the relevance of economic capital, more specifically, sport clubs' tendency to become an employer. Previously based almost entirely on volunteer activities, full-time coaches and general managers are now commonplace in grassroots clubs.

Clubs reported that their average club turnover has risen, corroborating Koski and Mäenpää’s (2018) longitudinal research on Finnish sport clubs since 1986. According to my interviewees, the items that have particularly increased in cost are fees paid for training shifts and employee costs. The latter include full-time and part-time 
employees of the sport clubs as well as instructors and coaches who receive a compensation. Regarding revenues, fees paid by households remain the main source of income for Finnish sport clubs.

Concerning the rewards offered to sport club officials, the spectrum of compensation has broadened. A basketball club chairman pointed out that 'we pay something to all of our coaches although none of them is full-time. They can decide whether they receive it as salary or expenses'. The compensation may be based on the number of hours, the number of events, while monthly payments are also common. Becoming an employer and handling additional financial transactions mean that clubs have entered formerly unknown territories; as financial regulations have to be complied with, The Finnish Tax Administration has responded by organising training for thirdsector organisations.

The second type of capital reflects increasing expectations of spaces and facilities. Although sport facilities in Finland have traditionally been provided by the public sector (Koski et al. 2015), my data indicates that private companies have increasingly offered options for clubs to use gyms, air domes and first-snow ski tracks, ${ }^{1}$ to name just a few such facilities. Further, some sport clubs have taken the initiative and constructed their own facilities, typically in collaboration with other actors such as the municipality, or other clubs. As a football club chairman pointed out: 'The footballpitch project in cooperation with the municipality was successful...we have our own pitch on the land owned by the municipality'. In fact, ownership of facilities may also provide additional sources of income by charging fees from other users. That is, owning

\footnotetext{
${ }^{1}$ The first-snow ski track is created by using snow stored from the previous winter in autumn before the weather allows cross-country skiing in natural conditions.
} 
or paying for privately owned facilities have become legitimate; what is more, it can yield a competitive advantage. However, there are differences between sports; a board member of one of the most successful athletics clubs stated that they use only municipality spaces. This is also the case with several other sports appearing in the research data such as martial arts, gymnastics and American football clubs.

The demand for facilities has shifted as an increasing number of clubs and participants began to require multifaceted facilities. Since training has become more systematic and professionalised, clubs look for spaces where complementary sessions, for example strength and conditioning, warm-up and cooling-down activities, can be undertaken. This implies competition for access to and control of economic capital, as well as to facilities. Better facilities have enabled clubs to lengthen the season in many sports. Accordingly, training all year round has become more common in a Nordic context, where many sports used to be seasonal due to the climate.

The third type of capital focuses on the changing language of this diversified field. In accordance with the changes presented, my data reflects that the sport club field has seen a shift in its logic and language. A chairman of a multi-sport club pointed out that 'the biggest challenge in an association is to find the common language and goals between all the various actors, such as parents, officials and the club itself'. These actors may interpret and implement elements that influence the club in various ways. A head of coaching, for example, embraces the latest approaches and corresponding language in coaching, having obtained a coaching qualification of the national federation, which promotes that same technical language. Further, setting up the participant pathways and the curricula corresponding to a given age group entails the diffusion of technical language of coaching. In the same way, formal education at 
universities and other institutions shapes norms in an organisational field. Sport clubs may end up employing similar individuals in similar positions.

Indeed, language plays a key role in operating a sport club: coaching guidelines, job descriptions, tournament manuals and regulations about using facilities reflect the extensive use of coaching, marketing and management vocabulary, thereby marking new forms of institutional practices and a shift in dominant cultural capital. These shifts can cause tensions given that participants, parents and voluntary coaches may experience emerging language and logics differently. Likewise, interviewees emphasised that different generations use communication devices and channels such as social media in diverse ways, which may create misunderstandings.

Another aspect of the changing language is an emerging consumerist narrative, which risks endangering the traditional motivations of civic organisation. Staging tournaments and summer camps as well as selling merchandising products are just some of the ancillary activities reflecting the emergence of commercial tendencies. According to Koski et al. (2015), participants' consumer-based mindset in Finland is manifested by taking part in activities in return for direct payments, leading to a lack of personal contribution, emotional ties, and as a result, jeopardising communality. More recently an emphasis on health has also intensified; an athletics club chairman pointed out that 'the pathway of an athlete [within the club] is discussed a lot, but I am talking about the pathway of a healthy adult, which is of key importance as well'. When looking at the verbiage of sport clubs' programmes, health-related activities for participant of various ages can be identified. This change is also exemplified in the Sports Club for Health approach (Finnish Olympic Committee 2017). Similarly, Lämsä $(2012,105)$ points to the 'increase in health-enhancing physical activities' when analysing the decreased importance of elite sport in Finland. 


\section{Regulatory structures}

The sport club field's regulative framework and governance highlights its growing complexity. An example are quality-assurance programmes that federations have introduced in several sports such as ice hockey, swimming and football. In these programmes, clubs may ascend to a higher category when fulfilling audit criteria. The chairman of a football club commented: 'We are focusing on developing our operation according to the Football Association's "club programme audit" so that we reach Level $4^{2}$. The swimming federation has advanced their programme in cooperation with a research institute to ensure the quality of audits. Such aspirations illustrate professionalisation prompted by normative pressure coming from sport federations.

In addition, the relevance of support schemes, through which funding can be applied for, to facilitate hiring employees and to implement sport-related projects, was identified in the data. The scheme- - with its objective to provide better services for the public good and to attract more participants - in its present form was launched by the Ministry of Education and Culture in 2009 (Koski 2012). These initiatives are also tools to exert power; while quality-assurance programmes that focus on competitive activities and talent development drive the interest of national sport federations, support schemes awarded by the Ministry rather reflect a sport-for-all logic. Successful applications for these resources require following detailed guidelines and reporting, therefore adding to the administrative burden of clubs. Consequently, these programmes have been criticised as they favour clubs that already possess more human resources and expertise.

\footnotetext{
${ }^{2}$ The Quality Assurance Program (Seurojen laatujärjestelmä) of the Football Association of
} Finland consists of five levels. The objective of the program is to comprehensively develop the operation of football clubs. 
Another element of governance in the field of sport clubs encompasses coaching and playing. Coaching education run by federations nowadays comprises numerous stages and pathways. My interview data also identified less formal means of providing education for coaches and instructors, including talent-coach schemes and coachingtutor programmes. Regarding the playing element, compulsory player licences and insurance have been introduced. Competition formats have become systematic even at youth level. These programmes, standards and accreditations highlighted throughout this section may be called soft regulatory structures; complying with these provide legitimacy within the organisational field (Greenwood et al. 2008).

In part as an attempt to respond to the changes presented above, formalisation has also appeared on the club level. Many sport clubs used to be fragmented in their structure and operation: teams of different ages were run independently within a club, generally with a separate budget; as fewer clubs employed people, most did not use office space; and training sessions traditionally took place in various venues. In contrast, when employing a general manager, head of youth or head of coaching, clubs' 'headquarters' have gained more control over the operations of the club and thus become more centralised. Organisation charts have been set up and the description of roles has been developed. A comment by a football club's chairman reflects this transformation: 'During the development process that started with launching our strategy nine years ago, we have clarified the profile of our club, and simultaneously a shift has taken place from individual teams to a unified sport club'.

Accordingly, clubs provide strategies, coaching guidelines, tournamentorganisational manuals and other documentation for their teams and members, and in this way they obtain more cultural capital and power over individual teams. Nevertheless, these changes appear to various degrees in different clubs, which is 
apparent with a floorball club interviewed, where teams are still independent, there is no employee hired by the club, and teams agree independently whether to pay compensation to coaches.

\section{Conclusions}

This article has employed a new institutionalist lens in order to gain more understanding about the changing organisational field of Finnish voluntary sport clubs. My dataexpert interviews from club officials and club documents - was analysed by drawing on O'Brien and Slack's (2003) analytical scheme, which signposts changes of the dominant logics in an organisational field. In the process of discussing these signposts of the changing logic, I have also explored how sport clubs have adjusted to as well as shaped the organisational field.

With respect to the number and nature of actors, and exchange processes- these were the first two signposts - sport clubs reported a growing involvement of the private sector and, accordingly, a widening range of roles and the appearance of specialists. Further, the public sector has increasingly expected organised civil activity to be 'a service producer with the expectation of results' (Koski 2012, 257) and to engage with other actors in the field (Alapuro 2010). As a result, actors with various experiences, education and values have appeared. The change and emergence of roles along the volunteer-full-time continuum is one of the key challenges of Finnish sport clubs, particularly given that volunteer commitment has become increasingly intermittent in recent decades (Koski 2012). Emerging roles and statuses mean that sport club officials are compensated in a multitude of ways. Further, diverse participant pathways that might cross over clubs have evolved, requiring to develop new types of relationships and networks between clubs. 
In terms of legitimate forms of capital - the third indicator-economic capital has gained more dominance as an increasing number of clubs have employed people and the average turnover of clubs has risen. In addition, demand from sport clubs for sport-specific facilities has grown; these facilities are often provided by the private sector or constructed with the involvement of several stakeholders across sectors. Access to or ownership of high-quality facilities may yield competitive advantage by enabling clubs to expand their season and earn extra income. Undertaking commercial activities has become legitimate as clubs attempting to satisfy the demands of participants. Simultaneously, the field's language has shifted and finding the common language among stakeholders may be a challenge. The professionalisation of coaching as well as the emerging consumer, management and health perspectives were exemplified in club documents that reveal the use of technical vocabulary. In so doing, new forms of language and practices have clearly become institutionalised.

Parallel to the aforementioned processes, the sport-club field has seen a shift in its regulatory structures - the fourth indicator - and become more complex and formalised; quality assurance programs and support schemes have appeared that reflect governing bodies seeking to exert power and shape the field. Coaching education has become more systematic and new competition formats have been introduced. Clubs have adapted by providing guidelines such as coaching principles, tournament manuals, facility operation guidelines and fundraising guides, as revealed in online club documents.

Many clubs have experienced challenges and uncertainty as they operate in domains that are different from their traditional operations. My data highlighted the challenges related to stakeholders' diversified expectations. Supporting the findings of Koski et al. (2015), challenges also include dealing with increasing participation costs 
and managing facilities. Clubs have explored new ways of operating, exemplified by the introduction of new positions and services along with becoming more self-aware and trying to identify a club profile; these practices can be seen as attempts to maintain legitimacy in the organisational field. Nevertheless, clubs with dissimilar profiles from one another and in different geographical locations have changed in diverse ways. Therefore, this organisational field should not be seen as homogenous; the variety of sport clubs needs to be appreciated.

Applying new institutional concepts such as the organisational field and the dominant logics allowed this research to contribute to theoretical discussions around the shifting roles of the three sectors and the changing expectations of sport clubs. It has been observed that, since the 1990s, Finnish sport clubs' operation has begun to reflect processes such as strategic planning and customer orientation (Koski and Heikkala 1998). Nevertheless, drawing on the concept of dominant logics in this study allowed a more nuanced investigation of these changes. Understanding the logics of public, private and third sectors have become necessary for the running of sport clubs. What is more, an environment with a unique combination of logics has emerged, with often multiple logics within a sport club.

Exploring the Finnish context has also revealed that changes in the dominant logics - facilitated by the introduction of support schemes - have occurred at pace in the past decade: employment has increased and new values and language infiltrated the field alongside traditional principles based on volunteerism and the association logic. Crucially, we need further research to investigate these logics more in detail. Overall, this study largely aligns with an existing body of knowledge suggesting that sport clubs have been expected to be involved in serving wider functions of sport, such as health, 
education, social cohesion and employment (Houlihan and Green 2009; Koski and Mäenpää 2018; Jones et al. 2018).

The results have implications for Finnish clubs facing the challenges discussed.

Given that a broad range of skills are needed to be able to work in a sport club environment, the findings will also be interest of sports federations and institutes providing tertiary education when devising courses and study materials. However, limitations of this study also need to be considered. With respect to the methodology, clubs were selected by convenience sampling, only one person was interviewed from each club and the data-collection timeframe was dictated by the seminars that took place between 2014 and 2017. Even though club documents were used to triangulate data, collecting data on the different levels of the clubs, such as the board, the operative level and the teams/participants, would have strengthened reliability.

Considering future research, studies should be conducted on sport clubs focusing on certain aspects such as the status of club officials, diverse participant pathways and club-owned facilities. Also, we need more understanding of the mechanisms of changes; that is, how ideas are diffused, translated or resisted by sport clubs. To achieve this, ethnographic and longitudinal designs are suggested.

\section{Acknowledgments}

The author gratefully acknowledges the insightful comments from Ben Powis, Kola Adeosun, Anna-Liisa Ojala, Sandy Adam, Polina Baum-Talmor and the anonymous reviewers.

\section{References}

Alapuro, Risto. 2010. "Introduction: Comparative Approaches to Associations and Civil Society in Nordic Countries." In Nordic Associations in a European Perspective, edited by Risto Alapuro and Henrik Stenius, 11-28. Baden-Baden: Nomos. 
Alastalo, Marja and Maria Åkerman. 2010. "Asiantuntijahaastattelun Analyysi:

Faktojen Jäljillä." In Haastattelun Analyysi, edited by Pirjo Nikander, Matti Hyvärinen, and Johanna Ruusuvuori, 372-392. Tampere: Vastapaino.

Augestad, Päl, Asle Bergsgard, and Atle Ø Hansen. 2006. "The Institutionalization of an Elite Sport Organization in Norway: The Case of "Olympiatoppen"." Sociology of Sport Journal 23 (3): 293-313.

Bettis, Richard A. and C. K. Prahalad. 1995. "The Dominant Logic: Retrospective and Extension." Strategic Management Journal 16 (1): 5-14.

Bourdieu, Pierre and Loïc Wacquant. 1992. An Invitation to Reflexive Sociology. Cambridge: Polity.

Boxenbaum, Eva and Stefan Jonsson. 2008. "Isomorphism, Diffusion and Decoupling." In The SAGE Handbook of Organizational Institutionalism, edited by Royston Greenwood, Christine Oliver, Kerstin Sahlin, and Roy Suddaby, 78-98. London: Sage.

Braun, Virginia and Victoria Clarke. 2006. "Using Thematic Analysis in Psychology." Qualitative Research in Psychology 3 (2): 77-101.

DiMaggio, Paul J. and Walter W. Powell. 1983. "The Iron Cage Revisited: Institutional Isomorphism and Collective Rationality in Organizational Fields." American Sociological Review 48 (2): 147-160.

Eurobarometer. 2017. Special Eurobarometer 472: Sport and Physical Activity: European Union.

Finnish Olympic Committee. 2017. "The Sports Clubs for Health (SCFORH) Approach." Accessed 14 December 2018. https://www.scforh.info/

Greenwood, Royston and Christopher. R. Hinings. 1996. "Understanding Radical Organizational Change: Bringing Together the Old and the New Institutionalism." The Academy of Management Review 21 (4): 1022-1040.

Greenwood, Royston, Christine Oliver, Roy Suddaby, and Kerstin Sahlin. 2008. "Introduction." In The SAGE Handbook of Organizational Institutionalism, edited by Royston Greenwood, Christine Oliver, Roy Suddaby and Kerstin Sahlin, 1-46. Los Angeles: Sage.

Heinemann, Klaus. 2004. Sportorganisationen: Verstehen und Gestalten [Understanding and Designing Sport Organizations]. Schorndorf: Hoffmann.

Heinilä, Kalevi. 1989. "The Sport Club as a Social Organization in Finland." International Review for the Sociology of Sport 24 (3): 225-248.

Houlihan, Barrie and Mick Green. 2009. Modernization and Sport: The Reform of Sport England and UK Sport. Loughborough: PSA. 
Itkonen, Hannu. 1991. "Tarmompa poekija ollaan": Tutkimus suomalaisen urheiluseuran muutoksesta ["We are Tarmo's Lads": Research about the Changes of a Finnish Sport Club]. Joensuu, Finland: University of Joensuu.

Itkonen, Hannu. 1996. Kenttien kutsu: Tutkimus liikuntakulttuurin muutoksesta [Call of the Playing Fields: A Study on the Changes of Exercising Culture]. Helsinki: Gaudeamus.

Itkonen, Hannu. 2002. Sport and Civil Society: Sociological Perspectives. Joensuu, Finland: University of Joensuu.

Itkonen, Hannu and Arto Nevala. 2012. Tarmon taipale - Varkauden Tarmon sata vuotta urheilun ja liikunnan yleisseurana 1912-2012 [The Journey of a 100-YearOld Sport Club: The History of Varkauden Tarmo]. Tampere, Finland: Suomen Yliopistopaino Oy.

Jones, Gareth J., Michael B. Edwards, Jason N. Bocarro, Kyle S. Bunds, and Jordan W. Smith. 2018. "A Structural Perspective of Cross-Sector Partnerships Involving Youth Sport Non-Profit Organizations." European Sport Management Quarterly 18 (2): 133-155.

Koski, Pasi. 2000. Maailma muиttuu, muиttuvatko seurat [Changing World, Changing Clubs]. Jyväskylä, Finland: University of Jyväskylä.

Koski, Pasi. 2009. Liikunta- ja urheiluseurat muutoksessa [Sports Clubs in Change]. Helsinki, Finland: SLU-paino.

Koski, Pasi. 2012. "Finnish Sports Club as a Mirror of Society." International Journal of Sport Policy 4 (2): 257-275.

Koski, Pasi and Juha Heikkala. 1998. Suomalaisten liikuntaorganisaatioiden muutos lajiliitot professionaalistumisen prosessissa [National Sports Organizations and the Process of Professionalisation]. Jyväskylä, Finland: University of Jyväskylä.

Koski, Pasi, Hannu Itkonen, Kati Lehtonen, and Hanna Vehmas. 2015. "Sport Clubs in Finland." In Sport Clubs in Europe: A Cross-National Comparative Perspective, edited by Christoph Breuer, Remco Hoekman, Siegfried Nagel and Harold Van der Werff, 147-160. Switzerland: Springer.

Koski, Pasi and Pasi Mäenpää. 2018. Suomalaiset liikunta- ja urheiluseurat muutoksessa 1986-2016 [Transition of Finnish Sports Clubs between 1986-2016]. Helsinki, Finland: Ministry of Education and Culture.

Laine, Antti and Hanna Vehmas, ed. 2017. The Private Sport Sector in Europe: A Cross-National Comparative Perspective. Switzerland: Springer.

Lämsä, Jari. 2012. "Finnish Elite Sport - from Class-Based Tensions to Pluralist Complexity." In Nordic Elite Sport: Same Ambitions, Different Tracks, edited by S. Svein Andersen and Lars Tore Ronglan, 83-106. Oslo: Universitetsforlaget. 
Mäenpää, Pasi and Sirpa Korkatti. 2012. Urheiluseurat 2010-luvulla [Sport Clubs in the 2010s]. Helsinki: Sporttipaino Oy.

Nagel, Siegfried, Torsten Schlesinger, Pamela Wicker, Jo Lucassen, Remco Hoekman, Harold van der Werff, and Christoph Breuer. 2015. "Theoretical Framework." In Sport Clubs in Europe: A Cross-National Comparative Perspective, edited by Christoph Breuer, Remco Hoekman, Siegfried Nagel and Harold van der Werff, 7 27. Switzerland: Springer.

O’Brien, Danny and Trevor Slack. 2003. "An Analysis of Change in an Organizational Field: The Professionalization of English Rugby Union." Journal of Sport Management 17 (4): 417-448.

O'Brien, Danny and Trevor Slack. 2004. "The Emergence of a Professional Logic in English Rugby Union: The Role of Isomorphic and Diffusion Processes." Journal of Sport Management 18 (1): 13-39.

Prahalad, C. K. and Richard A. Bettis. 1986. "The Dominant Logic: A New Linkage between Diversity and Performance." Strategic Management Journal 7 (6): 485501.

Puronaho, Kari. 2014. Drop-out vai throw-out. Tutkimus lasten ja nuorten liikuntaharrastusten kustannuksista [Drop-Out or Throw-Out. A Study about the Costs of Sport Participation of Children and Youth]. Helsinki, Finland: Ministry of Education and Culture.

Saunders, Mark, Philip Lewis, and Adrian Thornhill. 2016. Research Methods for Business Students (7th edition). Essex: Pearson Education Limited.

Schlesinger, Torsten and Siegfried Nagel. 2015. "Does Context Matter? Analysing Structural and Individual Factors of Member Commitment in Sport Clubs." European Journal for Sport and Society 12 (1): 53-77.

Scott, W. Richard. 2008. "Approaching Adulthood: The Maturing of Institutional Theory." Theory and Society 37 (5): 427-442.

Scott, W. Richard. 2014. Institutions and Organizations: Ideas, Interests, and Identities. (4th edition). London: SAGE.

Skille, Eivind Å. 2008. "Understanding Sport Clubs as Policy Implementers: A Theoretical Framework for the Analysis of the Implementation of Central Sport Policy through Local and Voluntary Sport Organizations." International Review for the Sociology of Sport 43 (2): 181-200.

Skille, Eivind Å. 2009. "State Sport Policy and Voluntary Sport Clubs: The Case of the Norwegian Sports City Program as Social Policy." European Sport Management Quarterly 9 (1): 63-79.

Skille, Eivind Å. 2011. "Change and Isomorphism: A Case Study of Translation Processes in a Norwegian Sport Club." Sport Management Review 14 (1): 79-88. 
Skirstad, Berit and Packianathan Chelladurai. 2011. "For 'Love' and Money: A Sports Club's Innovative Response to Multiple Logics." Journal of Sport Management 25 (4): 339-353.

Sparkes, Andrew C. and Brett Smith. 2014. Qualitative Research Methods in Sport, Exercise and Health: From Process to Product. Abingdon: Routledge.

Stenling, Cecilia and Josef Fahlén. 2009. "The Order of Logics in Swedish Sport Feeding the Hungry Beast of Result Orientation and Commercialization." European Journal for Sport and Society 6 (2): 121-134.

Szerovay, Mihaly, Szilvia Perényi, and Hannu Itkonen. 2016. "Glocal Processes in Peripheral Football Countries: Elite Youth Football Clubs in Finland and Hungary." Hungarian Review of Sport Science 17 (65): 26-33.

Van der Roest, Jan-Willem. 2016. "Consumerism in Sport Organizations:

Conceptualizing and Constructing a Research Scale." European Journal for Sport and Society 13 (4): 362-384.

Vehmas, Hanna and Kalervo Ilmanen. 2013. "Finland." In Comparative Sport Development: Systems, Participation and Public Policy, edited by Kristin Hallmann and Karen Petry, 47-60. New York: Springer.

Vos, Steven, Diane Breesch, Stefan Késenne, Jo Van Hoecke, Bart Vanreusel, and Jeroen Scheerder. 2011. "Governmental Subsidies and Coercive Pressures. Evidence from Sport Clubs and their Resource Dependencies." European Journal for Sport and Society 8 (4): 257-280.

Wengraf, Tom. 2001. Qualitative Research Interviewing: Biographic Narrative and Semi-Structured Methods. London: SAGE. 